\title{
EXPERIMENTAL STUDY FOR ENERGY DISSIPATION USING STILLING BASIN WITH ONE AND TWO CONSECUTIVE DROPS
}

\author{
Qassem H. Jalut ${ }^{1}$, Nagla F. El-Baaja ${ }^{2}$ \\ ${ }^{1}$ Assistant Professor College of Engineering, Diyala University, Iraq. \\ ${ }^{2}$ Assistant Lecturer, University of Garyounis, College of Engineering, Libya. \\ E-mail: qjalut@gmail.com
}

(Received: 9/10/2012; Accepted: 17/7/2013)

\begin{abstract}
The scour at downstream of hydraulic structures is one of the major concern in its stability analysis and operation .The excess energy existing immediately downstream of such structures has to be controlled. Hence, it is necessary to design and install a device for dissipating excess energy in order to prevent downstream scour. The drop structures is one of the commonly structures used for dissipating excess energy.

In the present study an experimental approach is employed through which different types of stilling basin with different heights were tested using one drop and two consecutive drops. Moreover the effect of the end sill and baffles with different heights and different bed slopes was investigated. The hydraulic parameters involved were measured experimentally using a model of straight drop installed in the available $\left(S_{6}\right)$ multi-purpose flume in the fluid mechanics lab at the Civil Engineering Department, University of Garyounis.

Results showed that, for one drop the presence of end sill reduced the length of the jump by a small value approximately $4 \%$ with an increase of relative energy loss by a small value. The increase of relative baffles block height increases the optimum relative height of drop $\left(w / y_{l}=6\right)$, and the relative energy loss .For two consecutive drops it was found that the most value of energy loss takes place in the second basin. The presences of end sill at the end of second basin increases the performance of second basin by small value approximately $5 \%$. It is also shown that increasing the relative height of baffles blocks lead to increases in the relative energy loss (within the ranges considered in this study), and the optimum relative baffle block height $h_{b} / y_{l}=0.77$ to 1.7 and bed slope is $1 / 50$.
\end{abstract}

Keywords: Stilling basin, energy dissipation, Scour, hydraulic jump. 


\section{INTRODUCTION:}

Many extensive and comprehensive studies have been presented to investigate the problem of energy dissipation downstream of hydraulic structures constructed in open channels. Different methods and techniques have been developed either to improve the efficiency of the existing dissipaters or to find new dissipaters that satisfy both high efficiency and minimum cost. These methods or techniques may be classified into: (a) energy dissipation using stilling basins, (b) energy dissipation by counter (reverse) flow and (c) energy dissipation on slopping surfaces.

Numerous studies have been made on the shape, dimensions and details of stilling basins. Chow (1959) made series of experiments on both continuous and dentate sills; the two main conclusions obtained were that the continuous sill is more efficient than dentate sill in stabilizing the forced hydraulic jump and in increasing energy dissipation, and at smaller Froude numbers $(F r l<5)$, the efficiency of the dentate sill is near that of the continuous one.

Pillai and Unny (1964) used new shapes of stilling basin appurtenances in the form of wedge blocks, with apex angle range of $60^{\circ}$ to $180^{\circ}$. Results of experiments indicated that blocks with an upstream angle of $120^{\circ}$ provide best performance among the other tested blocks. When these blocks were cut back at an angle of $90^{\circ}$, its efficiency was increased and the expected cavitations may be reduced. Basco and Adams (1971) studied the effect of block dimensions, spacing (in longitudinal and transversal directions), and location on the drag force caused by the flow. The horizontal force coefficient, $\varphi=F B / P B$, is considered as a measure of the relative effectiveness of the blocks, where $F B$ is the total drag force on the baffle blocks, and $P B$ is the pressure force resulting by the sequent depth of a free jump $y 2$. Basco and Adams found that increasing the blockage or moving the second block row very close to the first one increase $\varphi$. Additional tasks indicated that the optimum performance occurs at a $50 \%$ blockage. Basco concluded that a single row of blocks is generally sufficient and adding a second staggered block row produced only a $5 \%$ to $10 \%$ increase in $\varphi$.

USCE Stilling Basin (1974): the U.S. Army Corps of Engineering (USCE 1974) proposed a stilling basin involving two rows of baffle blocks and an end sill. Kraatz and Mahajan (1975) found that the impact block type basin provides good energy dissipation under low heads and is suitable when the tail water level (TWL) is greater than the sequent depth. They give the dimension of the stilling basin as follows:

$\mathrm{L}_{\mathrm{B}}=\mathrm{L}_{\mathrm{d}}+2.55 \mathrm{y}_{\mathrm{c}}$

Location of baffle block $L_{l}=L_{d}+0.8 y_{C}$

Baffle block height $h_{b}=0.8 y_{c}$ 
Width of baffle block $w_{b}=0.4 y_{c} \ldots \ldots \ldots \ldots \ldots \ldots \ldots \ldots$ (4)

Spacing between baffles blocks $S_{b}=0.4 y_{c} \ldots \ldots \ldots \ldots \ldots \ldots$ (5)

End sill height $S_{e 1}=0.4 y_{c} \ldots \ldots \ldots \ldots \ldots \ldots \ldots \ldots \ldots \ldots$ (6)

Min. tail water depth $=2.15 y_{c} \ldots \ldots \ldots \ldots \ldots \ldots \ldots \ldots \ldots$ (7)

Bhowmik and Nani (1975) presented a design of stilling basin especially for a range of Froude number from 2.5 to 4.5. The oblique orientation of the baffles in this basin was adopted to force the high velocity jets to intermix thoroughly giving the appearance of a uniform mixture of entrained air and water, which in turn, results in increasing of energy dissipation. Abd El Lateef (1986) and Abd El Salam et. al. (1986) carried out an experimental study on rough bed with brass cubes located in staggered position downstream a sluice gate. Different bed roughness intensities were used in the range of Froude number from 3.48 to 10.15 . It was found that the bed roughness intensity $I=10 \%$ gives the optimum length of stilling basin and maximum relative energy losses through the formed hydraulic jump.

Narayanaet. al. (1989) studied a new shape of baffle blocks which can be used to minimize the length of the downstream stilling basin and the downstream scour hole in the same time, and they compare their results with other types of stilling basins. Mohamed Ali, H.S. (1991) studied the effect of roughened bed stilling basin on the length of rectangular hydraulic jump, because of reducing hydraulic jump lead to reducing of stilling basin dimension. He concluded that the length of the hydraulic jump is clearly reduced by using cube roughness, it agrees with USBR (basin II) for large $F r l$ and gives more reduction for a value of Frl less than 6 .

Hager and Damel (1992) studied a stilling basin provided with an intermediate sill. The effect of a continuous, transverse sill on the hydraulic jump is analyzed. It was found that sill-controlled energy dissipater may be much more efficient, and requires both less tail water and basin length compared with a free jump. From the experimental model, they defined the length of the basin as the end of bottom roller.

EI-Saiyad (1994) as a result of experimental study concluded that continues sill of vertical upstream face causes a scour depth less than that of sloped upstream one, the end sill increases the scour depth and throws the scour hole far from the apron, the scour depth decreases by increasing the sill height of vertical upstream face and the stilling basin of two rows of baffle piers in staggered position decreases the scour hole than that of one row.

EL-Masry (2001) studied the effect of double row of baffle angels on the scour hall downstream heading up structure. They changed the position of double row to achieve the 
best location of baffles that minimize the dimensions of scour hall .Awad (2004) studied successful drop structure of standard design for a drop height up to $5 \mathrm{~m}$. The "Inlet drop spillway" consists of a drop and a stilling basin, the stilling basin of this drop is provided with an end sill and a longitudinal sill .He reported that if the tail water level is too low, the free jump will shoot. If extended to a larger length, the velocity gradient will become small. Consequently, the stilling basin must be lengthened enough so that jump and eddy zones will finish within it, leading to an increase in the construction costs.

\section{THEORETICAL APPROACH OF STUDY}

The interrelationships between different parameters were correlated by using the dimensional analysis. Dimensional analysis using Buckingham's theorem is mainly aimed to obtain the relationships for the relative energy loss, the relative length of the jump, the relative depth of the water, the relative height of the jump, the relative drop height, relative baffle block height, and the relative end sill height. The various parameters and variables that are affecting the characteristics of the free hydraulic jump formed downstream of one drop are presented in figure (3.1), these parameters can be classified into three main groups namely,

\section{(1) Boundary dimensions}

w: drop height (L),LB : basin length (L), Se1: end sill height (L), hb baffles blockheight (L), wb : width of baffle blocks (L), B: width of the channel (L), and (1/Z): bed slope $\left(\mathrm{F}^{0} \mathrm{~L}^{0} \mathrm{~T}^{0}\right)$.

\section{(2) Flow dimensions}

y1: initial water depth of the jump (L); y2: sequent water depth of the jump (L); Lj: length of the jump (L); v: velocity of the flow $\left(\mathrm{LT}^{-1}\right)$, and $\mathrm{Q}$ : discharge passing through the flume ( $\left.\mathrm{L}^{3} \mathrm{~T}^{-1}\right)$.

\section{(3) Fluid dimensions}

$\rho$ : mass density of water $\left(\mathrm{FL}^{-4} \mathrm{~T}^{2}\right) ;{ }^{\mu}$ : dynamic viscosity of water $\left(\mathrm{FL}^{-2} \mathrm{~T}\right)$, and

g: gravitational acceleration $\left(\mathrm{LT}^{-2}\right)$.

For the above case, dimensional analysis was used and the relations of the relative jump length, the efficiency of the basin, relative energy loss, and sequent depth ratio may be written in forms of: 


$$
\begin{aligned}
& \frac{\mathrm{L}_{\mathrm{j}}}{\mathrm{y}_{1}}=\mathrm{f}\left(\mathrm{F}_{\mathrm{r} 1}, \frac{\mathrm{w}}{\mathrm{y}_{1}}, \frac{\mathrm{y}_{0}}{\mathrm{y}_{1}}, \frac{\mathrm{y}_{2}}{\mathrm{y}_{1}}, \text { slope }\right) . . \\
& \frac{\mathrm{E}_{2}}{\mathrm{E}_{1}}=\mathrm{f}\left(\mathrm{F}_{\mathrm{r} 1}, \frac{\mathrm{w}}{\mathrm{y}_{1}}, \frac{\mathrm{y}_{0}}{\mathrm{y}_{1}}, \frac{\mathrm{y}_{2}}{\mathrm{y}_{1}}, \text { slope }\right) \ldots . \\
& \frac{\mathrm{E}_{\mathrm{L}}}{\mathrm{E}_{1}}=\mathrm{f}\left(\mathrm{F}_{\mathrm{r} 1}, \frac{\mathrm{w}}{\mathrm{y}_{1}}, \frac{\mathrm{y}_{0}}{\mathrm{y}_{1}}, \frac{\mathrm{y}_{2}}{\mathrm{y}_{1}}, \text { slope }\right) . . \\
& \frac{\mathrm{y}_{2}}{\mathrm{y}_{1}}=\mathrm{f}\left(\mathrm{F}_{\mathrm{r} 1}, \frac{\mathrm{w}}{\mathrm{y}_{1}}, \frac{\mathrm{y}_{0}}{\mathrm{y}_{1}}, \text { slope }\right) \ldots \ldots . .
\end{aligned}
$$

The various parameters and variables that affect the characteristics of the free hydraulic jump formed downstream of one drop in a stilling basin provided with a continuous end sill and cubic baffle blocks are presented in figure (2).

Dimensional analysis was used and the relations of the relative jump length, the efficiency of the basin, relative energy loss, and sequent depth ratio may be written in forms of:

$$
\begin{aligned}
& \frac{L_{j}}{y_{1}}=f\left(F_{r 1}, \frac{w}{y_{1}}, \frac{y}{y_{1}}, \frac{2}{y}, \frac{S_{e 1}}{y}, \frac{w}{y_{1}}, \frac{b}{y} \text {, slope }\right) \\
& \frac{E_{2}}{E}=f\left(F_{r 1}, \frac{w}{y_{1}}, \frac{0}{y}, \frac{2}{y_{1}}, \frac{e_{1}}{y}, \frac{b}{y}, \frac{b}{y_{1}}, \text { slope }\right) \\
& \frac{E_{L}}{E}=f\left(F_{r 1}, \frac{w}{y}, \frac{0}{y}, \frac{2}{y}, \frac{e_{1}}{y}, \frac{b}{y}, \frac{b}{y}, \text { slope }\right) \\
& \frac{\mathrm{y}_{2}}{\mathrm{y}_{1}}=\mathrm{f}\left(\mathrm{F}_{\mathrm{r} 1}, \frac{\mathrm{w}}{\mathrm{y}}, \frac{\mathrm{y}}{\mathrm{y}}, \frac{\mathrm{S}}{\mathrm{y}} \mathrm{e}_{1}, \frac{\mathrm{w}}{\mathrm{y}}, \frac{\mathrm{b}}{\mathrm{y}}, \text { slope }\right) .
\end{aligned}
$$

In the case of the basin which has an end sill only without baffle blocks the previous equations can be written as following:

$$
\begin{aligned}
& \frac{\mathrm{L}_{\mathrm{j}}}{\mathrm{y}_{1}}=\mathrm{f}\left(\mathrm{F}_{\mathrm{r} 1}, \frac{\mathrm{w}}{\mathrm{y}_{1}}, \frac{\mathrm{y}}{\mathrm{y}_{1}}, \frac{\mathrm{y}_{2}}{\mathrm{y}_{1}}, \frac{\mathrm{S}_{\mathrm{e} 1}}{\mathrm{y}_{1}}, \text { slope }\right) . \\
& \frac{\mathrm{E}_{2}}{\mathrm{E}_{1}}=\mathrm{f}\left(\mathrm{F}_{\mathrm{r} 1}, \frac{\mathrm{w}}{\mathrm{y}_{1}}, \frac{\mathrm{y}_{0}}{\mathrm{y}_{1}}, \frac{\mathrm{y}_{2}}{\mathrm{y}_{1}}, \frac{\mathrm{S} \mathrm{e}_{1}}{\mathrm{y}_{1}}, \text { slope }\right) . . . .
\end{aligned}
$$




$$
\begin{aligned}
& \frac{E_{L}}{E_{1}}=f\left(F_{r 1}, \frac{w}{y}, \frac{y_{0}}{y_{1}}, \frac{y_{2}}{y_{1}}, \frac{e_{1}}{y_{1}}, \text { slope }\right) \\
& \frac{y_{2}}{y_{1}}=f\left(F_{r 1}, \frac{w}{y_{1}}, \frac{y_{0}}{y_{1}}, \frac{y_{2}}{y_{1}}, \frac{S_{e 1}}{y}, \text { slope }\right) . . .
\end{aligned}
$$

\section{DIMENSIONAL ANALYSIS FOR TWO CONSECUTIVE DROPS}

The different elements of such a stilling basin are presented in figure (3) which shows stilling basin downstream two drops in the case of plain stilling basin (no end sill no baffle blocks in the second basin) with the following relations:

Efficiency of the total basin:

$$
\frac{\mathrm{E}_{5}}{\mathrm{E}_{1}}=\mathrm{f}\left(\mathrm{F}_{\mathrm{r} 1}, \frac{\mathrm{y}_{0}}{\mathrm{y}_{1}}, \frac{\mathrm{y}_{2}}{\mathrm{y}_{1}}, \frac{\mathrm{y}_{3}}{\mathrm{y}_{1}}, \frac{\mathrm{y}_{4}}{\mathrm{y}_{1}}, \text { slope }, \frac{\mathrm{h}_{\mathrm{b} 1}}{\mathrm{y}_{1}}, \frac{\mathrm{w}}{\mathrm{y}_{1}}, \frac{\mathrm{w}_{\mathrm{b} 1}}{\mathrm{y}_{1}}, \frac{\mathrm{S}_{\mathrm{e} 1}}{\mathrm{y}_{1}}, \frac{\mathrm{S}_{\mathrm{e} 2}}{\mathrm{y}_{1}}, \frac{\mathrm{y}_{5}}{\mathrm{y}_{1}}\right)=0 .
$$

Efficiency of the first basin:

$$
\frac{\mathrm{E}_{3}}{\mathrm{E}_{1}}=\mathrm{f}\left(\mathrm{F}_{\mathrm{r} 1}, \frac{\mathrm{y}_{0}}{\mathrm{y}_{1}}, \frac{\mathrm{y}_{2}}{\mathrm{y}_{1}}, \frac{\mathrm{y}_{3}}{\mathrm{y}_{1}}, \frac{\mathrm{y}_{4}}{\mathrm{y}_{1}}, \text { slope }, \frac{\mathrm{h}_{\mathrm{b} 1}}{\mathrm{y}_{1}}, \frac{\mathrm{w}}{\mathrm{y}_{1}}, \frac{\mathrm{w}_{\mathrm{b} 1}}{\mathrm{y}_{1}}, \frac{\mathrm{S}_{\mathrm{e} 1}}{\mathrm{y}_{1}}, \frac{\mathrm{S}_{\mathrm{e} 2}}{\mathrm{y}_{1}}, \frac{\mathrm{y}_{5}}{\mathrm{y}_{1}}\right)=0 .
$$

Relative end sill height of the first basin:

$$
\frac{\mathrm{S}_{\mathrm{e} 1}}{\mathrm{y}_{1}}=\mathrm{f}\left(\mathrm{F}_{\mathrm{r} 1}, \frac{\mathrm{y}_{0}}{\mathrm{y}_{1}}, \frac{\mathrm{y}_{2}}{\mathrm{y}_{1}}, \frac{\mathrm{y}_{4}}{\mathrm{y}_{1}}, \frac{\mathrm{h}_{\mathrm{b} 1}}{\mathrm{y}_{1}}, \frac{\mathrm{w}}{\mathrm{y}_{1}}, \text { slope, } \frac{\mathrm{w}_{\mathrm{b} 1}}{\mathrm{y}_{1}}, \frac{\mathrm{y}_{5}}{\mathrm{y}_{1}}, \frac{\mathrm{S}_{\mathrm{e} 2}}{\mathrm{y}_{1}}, \frac{\mathrm{y}_{3}}{\mathrm{y}_{1}}\right)=0 .
$$

Relative end sill height of the second basin:

$$
\frac{\mathrm{S}_{\mathrm{e} 2}}{\mathrm{y}_{1}}=\mathrm{f}\left(\mathrm{F}_{\mathrm{r} 1}, \frac{\mathrm{y}_{0}}{\mathrm{y}_{1}}, \frac{\mathrm{y}_{2}}{\mathrm{y}_{1}}, \frac{\mathrm{y}_{4}}{\mathrm{y}_{1}}, \frac{\mathrm{h}_{\mathrm{b}}}{\mathrm{y}_{1}}, \frac{\mathrm{w}}{\mathrm{y}_{1}}, \text { slope }, \frac{\mathrm{w}_{\mathrm{b} 1}}{\mathrm{y}_{1}}, \frac{\mathrm{y}_{5}}{\mathrm{y}_{1}}, \frac{\mathrm{S}_{\mathrm{e} 1}}{\mathrm{y}_{1}}, \frac{\mathrm{y}_{3}}{\mathrm{y}_{1}}\right)=0
$$

For the case of end sill only at the end of second basin, the dimensionless equations may be written in the following forms:

$$
\begin{aligned}
& \frac{E_{5}}{E_{1}}=f\left(F_{r 1}, \frac{y_{0}}{y_{1}}, \frac{y_{2}}{y_{1}}, \frac{y_{3}}{y_{1}}, \frac{y_{4}}{y_{1}}, \frac{w}{y_{1}}, \frac{S_{e}}{y_{1}}, \frac{S_{e}}{y_{1}}, \frac{y_{5}}{y_{1}}, \text { slope }\right) \\
& \frac{E_{3}}{E_{1}}=f\left(F_{r 1}, \frac{y_{0}}{y_{1}}, \frac{y_{2}}{y_{1}}, \frac{y_{3}}{y_{1}}, \frac{y_{4}}{y_{1}}, \frac{w}{y_{1}}, \frac{S_{e}}{y_{1}}, \frac{S_{e}}{y_{1}}, \frac{y_{5}}{y_{1}}, \text { slope }\right) \\
& \frac{\mathrm{S}_{\mathrm{e} 1}}{\mathrm{y}_{1}}=\mathrm{f}\left(\mathrm{F}_{\mathrm{r} 1}, \frac{\mathrm{y}_{0}}{\mathrm{y}_{1}}, \frac{\mathrm{y}_{2}}{\mathrm{y}_{1}}, \frac{\mathrm{y}_{3}}{\mathrm{y}_{1}}, \frac{\mathrm{y}_{4}}{\mathrm{y}_{1}}, \frac{\mathrm{w}}{\mathrm{y}_{1}}, \frac{\mathrm{S}_{\mathrm{e} 2}}{\mathrm{y}_{1}}, \frac{\mathrm{y}_{5}}{\mathrm{y}_{1}}, \text { slope }\right)
\end{aligned}
$$


$\frac{\mathrm{S}_{\mathrm{e} 2}}{\mathrm{y}_{1}}=\mathrm{f}\left(\mathrm{F}_{\mathrm{r} 1}, \frac{\mathrm{y}_{0}}{\mathrm{y}_{1}}, \frac{\mathrm{y}_{2}}{\mathrm{y}_{1}}, \frac{\mathrm{y}_{3}}{\mathrm{y}_{1}}, \frac{\mathrm{y}_{4}}{\mathrm{y}_{1}}, \frac{\mathrm{w}}{\mathrm{y}_{1}}, \frac{\mathrm{S}_{\mathrm{e} 1}}{\mathrm{y}_{1}}, \frac{\mathrm{y}_{5}}{\mathrm{y}_{1}}\right.$, slope $)$.

Also for the case of no end sill at the end of second basin or baffles blocks within the stilling basin figure (4) the dimensionless equations my written in the following forms

$$
\begin{aligned}
& \frac{\mathrm{E}_{5}}{\mathrm{E}_{1}}=\mathrm{f}\left(\mathrm{F}_{\mathrm{r} 1}, \frac{\mathrm{y}_{0}}{\mathrm{y}_{1}}, \frac{\mathrm{y}_{2}}{\mathrm{y}_{1}}, \frac{\mathrm{y}_{3}}{\mathrm{y}_{1}}, \frac{\mathrm{y}_{4}}{\mathrm{y}_{1}}, \frac{\mathrm{w}}{\mathrm{y}_{1}}, \frac{\mathrm{S}_{\mathrm{e} 1}}{\mathrm{y}_{1}}, \frac{\mathrm{y}_{5}}{\mathrm{y}_{1}}, \text { slope }\right) \\
& \frac{E_{3}}{E_{1}}=f\left(F_{r 1}, \frac{y_{0}}{y_{1}}, \frac{y_{2}}{y_{1}}, \frac{y_{3}}{y_{1}}, \frac{y_{4}}{y_{1}}, \frac{w}{y_{1}}, \frac{S_{e}}{y_{1}}, \frac{y_{5}}{y_{1}}, \text { slope }\right) . \\
& \frac{\mathrm{S}_{\mathrm{e} 1}}{\mathrm{y}_{1}}=\mathrm{f}\left(\mathrm{F}_{\mathrm{r} 1}, \frac{\mathrm{y}_{0}}{\mathrm{y}_{1}}, \frac{\mathrm{y}_{2}}{\mathrm{y}_{1}}, \frac{\mathrm{y}_{3}}{\mathrm{y}_{1}}, \frac{\mathrm{y}_{4}}{\mathrm{y}_{1}}, \frac{\mathrm{w}}{\mathrm{y}_{1}}, \frac{\mathrm{y}_{5}}{\mathrm{y}_{1}}, \text { slope }\right) .
\end{aligned}
$$

\section{EXPERIMENTAL SETUP AND PROGRAM}

The experiments were conducted in the hydraulics and water engineering laboratory of the Faculty of Engineering, University of Garyounis. One flume is used in this work. The flume is of relatively large scale (30 $\mathrm{cm}$ bed width). It is of recirculation type and a closed operating system with overall length of $15.57 \mathrm{~m}$. The inlet and the outlet parts are connected to the flume. The inlet part, the working section and the outlet part are of length $1.37,12.50$ and $1.70 \mathrm{~m}$, respectively. A general isometric view of the flume is shown in figure (5).

\section{The Tested Models}

The tested models are made of hardwood of thickness $0.5 \mathrm{~cm}$ and are used to make different heights of drop and make multi consecutive drops. Downstream of each drop there is a stilling basin with length of $78 \mathrm{~cm}$. Each stilling basin consists of an end sill at its end and interior baffles blocks. A total of 6 models are tested. Each model is tested using different discharges ranging from 4 to 20 lit/sec. Each model is tested by using different heights of end sill, different height of baffle blocks and different bed slopes of flume. Figures (6, 7, and 8) show the different elements of each basin, and the details of the different test models are listed in a flow chart shown in figures (9 and 10).

\section{RESULTS AND DISCUSSION}

The effects of the following parameters which gives the minimum length of hydraulic jump and the maximum energy dissipation were discussed in this study: 
1. Froude number (Fr1)

2. Relative height of the drop (w/y1)

3. Relative height of the baffle blocks (hb/y1)

4. Relative height of the end sill (Se1/y1)

5. Bed slope (1/Z)

The following cases were investigated and the results were presented graphically for each case:

\section{1) Case of One Drop}

\section{a. Flat Case (no end sill and no baffle blocks)}

Figures (11), (12) and (13) show the relationship between initial Froude number and each of the relative depth ratio, the relative energy loss and the relative length of the jump through the basin at different values of drop height. $w=6,12,18,24$ and $30 \mathrm{~cm}$, respectively.

\section{b. Case of Presence of End Sill}

The presence of end sill, different bed slopes and its effect on the characteristics of flow through the downstream stilling basin of a one drop is presented. Figures (14, 15 and 16) are used to show the relationship between initial Froude number and the relative depth ratio at different values of bed slopes, drop height and end sill height for this case.

\section{c. Case of Presence of End Sill and Baffle Blocks}

Figures (17, 18, and 19) show the relationship between initial Froude number and the relative depth ratio at different values of baffle block heights, different bed slopes, and different drop heights for the case ofend sill and baffle blocks. These figures show also the effect of the above parameters on the characteristics of flow through the downstream stilling basin of a one drop. Figures (20 and 21) represent two photos to show the experimental setup and Baffle block heights respectively.

\section{2) Case of Two Consecutive Drops}

In this section the experimental data collected for the case of two consecutive drops, which will be presented to correlate the relationships between Froude number and the different basins efficiency, and the relative energy loss through each basin.

a. Flat case (no end sill nor baffle Blocks on the lower basin). 
Figure (22) is a photo for experimental setup for the case of no end sill and no baffle blocks in the lower basin. The performance of total basin is presented in figures $(23,24)$. Figure (23) shows the relationship between initial Froude number and the relative energy loss through the total basin.

\section{b. Case of Presence of End Sill}

The relationship between initial Froude number and the relative energy loss of the basin in the case where the second basin operate with end sill is viewed in figure (24).

\section{d. Case of Presence of End Sill and Baffle Blocks}

Experimental setup for the case of presence of end sill and baffle blocks can be seen in photo presented in figure (25). Figure (26, 27 and 28) show the relationship between initial Froude number and the relative energy loss of the upper basin and for lower basin.

\section{SUMMARY}

Experimental and theoretical studies were carried out in order to investigate a suitable stilling basin downstream drop structures to contain the formed hydraulic jump. Two cases were studied in a rectangular section, one of them is a model for one drop structure, and the other one is a model for two consecutive drops. The different characteristics of flow downstream of drops were studied under the effect of end sill with different baffle blocks heights and different bed slopes, with a specific range of Froude number.

The theoretical study depends on the basics of dimensional analysis in order to obtain a dimensionless equation to correlate different relationships between the different parameters, which affect the flow characteristics, such as, depth ratio of the jump, length of the hydraulic jump, and the energy loss through the basin.

\section{CONCLUSIONS}

\section{Case of One Drop}

1. The relative depth of the jump, the relative energy loss and the relative length of the jump increase with the increase of Froude number in the cases of (flat surface downstream drop or presence of end sill or baffle blocks).

2. The presence of end sill increases the relative energy loss by a small value, and decreases the relative water depth by a small value also.

3. The relative depth of the jump and the relative length of the jump decrease with the increase of the relative height of baffles used, while the relative energy loss increases. 
4. It was found that, for the same bed slope the optimum relative height of drop $\left(w / y_{1}\right)$, which gives maximum energy loss, minimum relative depth of jump and minimum relative length of jump is approximately 6 .

\section{Case of Two Drops}

1. Presence of end sill at the end of upper basin affects greatly the performance of the two basins.

2. The relative energy loss increases with the increases of the relative height of the baffles (within the ranges considered in this study).

3. It was found that, for the bed slope $1 / 50$ the optimum relative baffle block height $h_{b} / y_{l}=0.77$ to 1.7 and $S_{e l} / y_{l}=1.1$ to 2.7 which gives maximum energy loss, minimum relative depth of jump and minimum relative length of jump.

\section{RECOMMENDATIONS}

1- It is very useful to construct a numerical model to predict the different characteristics of flow at downstream of the drop structure based on the experimental results found herein.

2- The study can be extended to include the submerged hydraulic flow conditions.

\section{REFERENCES}

1- Abd El Lateef, M., (1986) "Energy Dissipation Downstream Low Head Irrigation Structure Using Bed Roughness" Ph.D. thesis, Ain Shams University, Cairo, Egypt.

2- Awad M. A., (2004) "Design of Stilling Basins Downstream Drop Structures" M. Sc. Thesis, Zagazig University, Zagazig, Egypt.

3- Chow V. T, (1959) “open channel hydraulics” McGraw-Hill book Company, Chapter 15, PP. 414-425.

4- EL-MasryA. A., (2001) "Minimization Of Scour Downstream Heading Up Structure Using Double Lines Of Angle Baffle" Sixth International Water Technology (IWTC), Alexandria, Egypt.

5- El Saiyad A. A., (1994) "Erosion And Rep-Rap Design For Hydraulic Structures Protection” Ph. D. thesis, Zagazig University, Zagazig, Egypt.

6- Hager W. H., (1992) "Energy Dissipaters And Hydraulic Jump" Kuwer Academic, Publishers, Vol.8.

7- Hager W.H. and Sinniger R. (1985) "Flow Characteristics of the Hydraulic Jump in a Stilling Basin with an Abrupt Bottom Rise" Journal of Hydraulic Research, Vol.23, PP.101-113. 
8- Kraatz D.B. and Mahajan I. K., (1975) "Small Hydraulic Structures Irrigation and Drainage" FAO, Rome, Papers No.26/1, 26/2.

9- Mohamed Ali H. S., (1991) "Effect Of Roughened Bed Stilling Basin On The Length Of Hydraulic Jump” Journal Of Hydraulic Engineering, ASCE, Vol.117, No.1, PP.83-93..

10- Narayana N. P., Arun G. and Ashoke K. D. (1989) “Hydraulic Jump Type Stilling Basin For Low Froude Numbers” Journal of Hydraulic Engineering, Vol.115, No.7.

11- Pillai N. N. and Unny T. E., (1964) "Shapes of Stilling Basin Appurtenance in the Form Wedge Blocks" Proc. ASCE. Journal of Hydraulic Division, Vol. 90 No.6, PP. 343-347.

12- United State Army, Crops Of Engineers, (1974), "Spillway Stilling Basin, Hydraulic Jump Type" Memorandum By Murphy, T. E.



Figure (1): Different characteristics of one drop in the flat case.



Figure (2): Different parameters of stilling basin with end sill and baffles block. 




Figure (3): Different parameters of stilling basin D.S. two consecutive drops.



Figure (4): Different parameters of stilling basin D.S two consecutive drops.

(The case of no end sill and baffle blocks) 




Figure (5): Photo represents the general view of the flume.

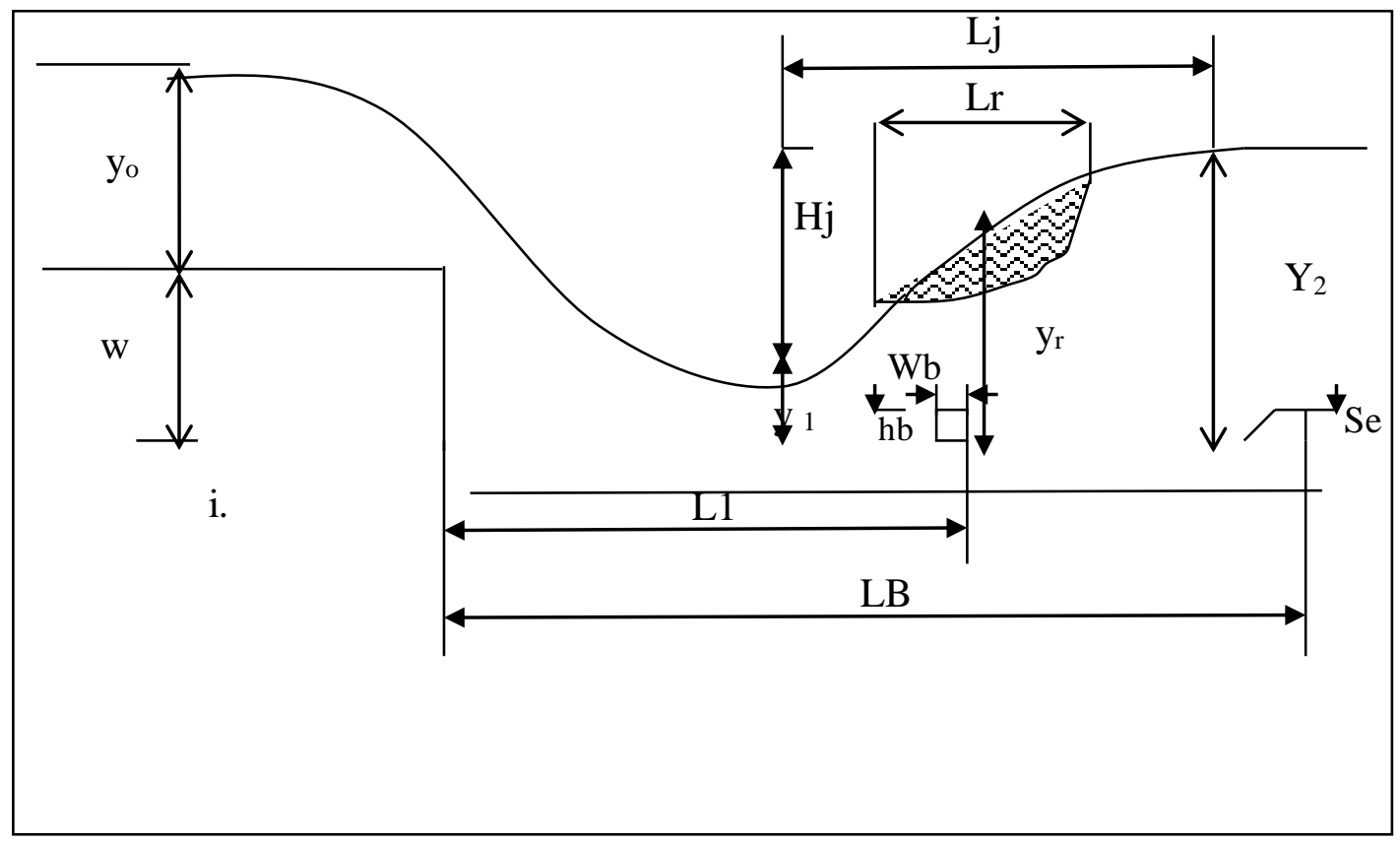

Figure (6): Details of one drop basin. 




Figure (7): Details of different bed slopes.

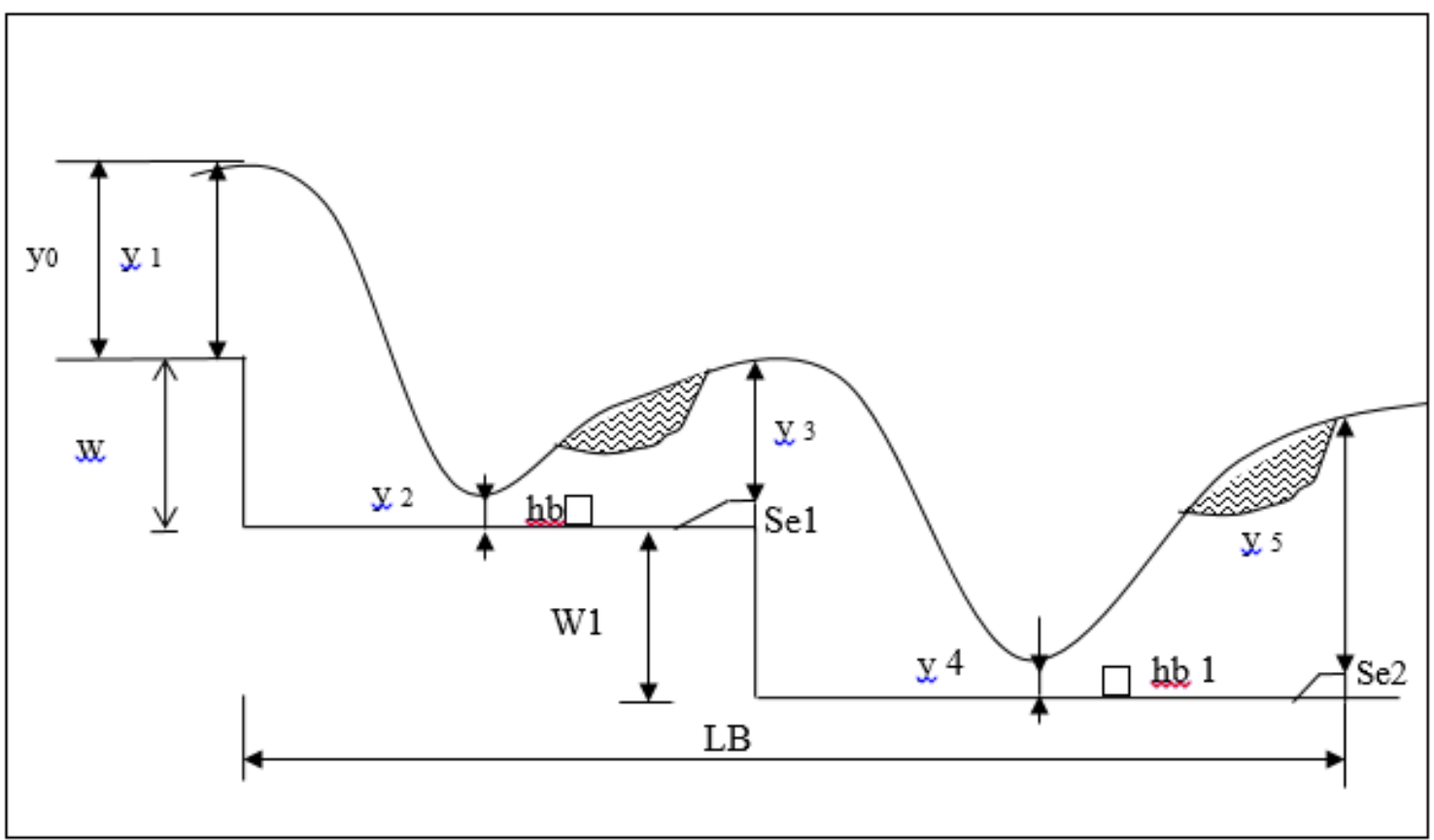

Figure (8): Details of two drops basin. 




Figure (9): flow chart for the experimental scenarios for the case of one drop.

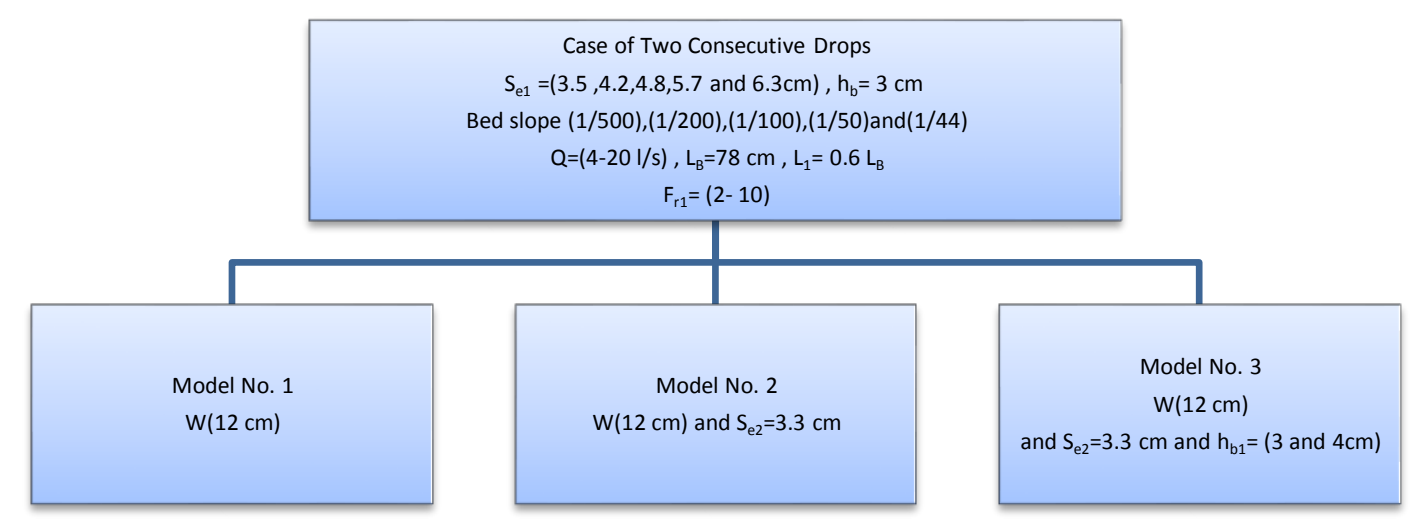

Figure (10): flow chart for the experimental scenarios for the case two consecutive drops. 
The relationship between initial Froude number and the relative depth ratio, relative energy loss and relative length of the jump:

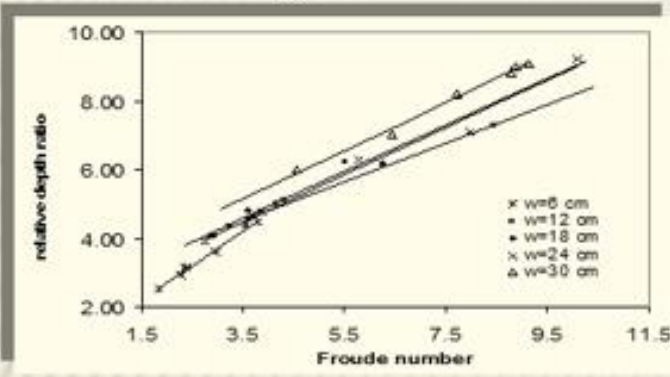

Figure(11)The relationship between Froude number and relative depth ratio for different height of drop.



Figure(12)The relationship between Froude number and relative energy loss for different height of drop.

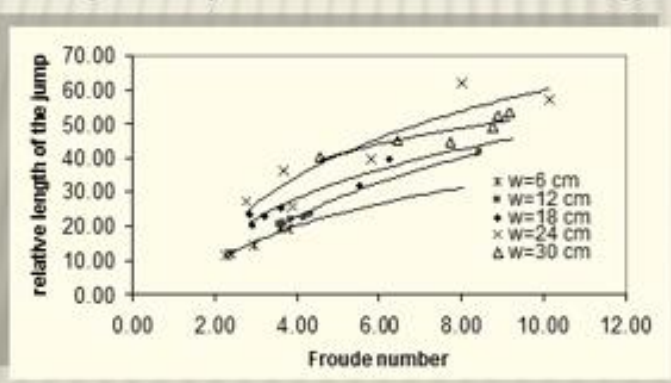

Figure(13)The relationship between Froude number and relative length of the jump for different height of drop.



Figure (14): The relationship between Fr1 and y2/y1 for different bed slopes, (b) for w=18 $\mathrm{cm}$. 




Figure (15): The relationship between Fr1 and EL/E1 for different bed slopes, (b) for $\mathrm{w}=18 \mathrm{~cm}$.

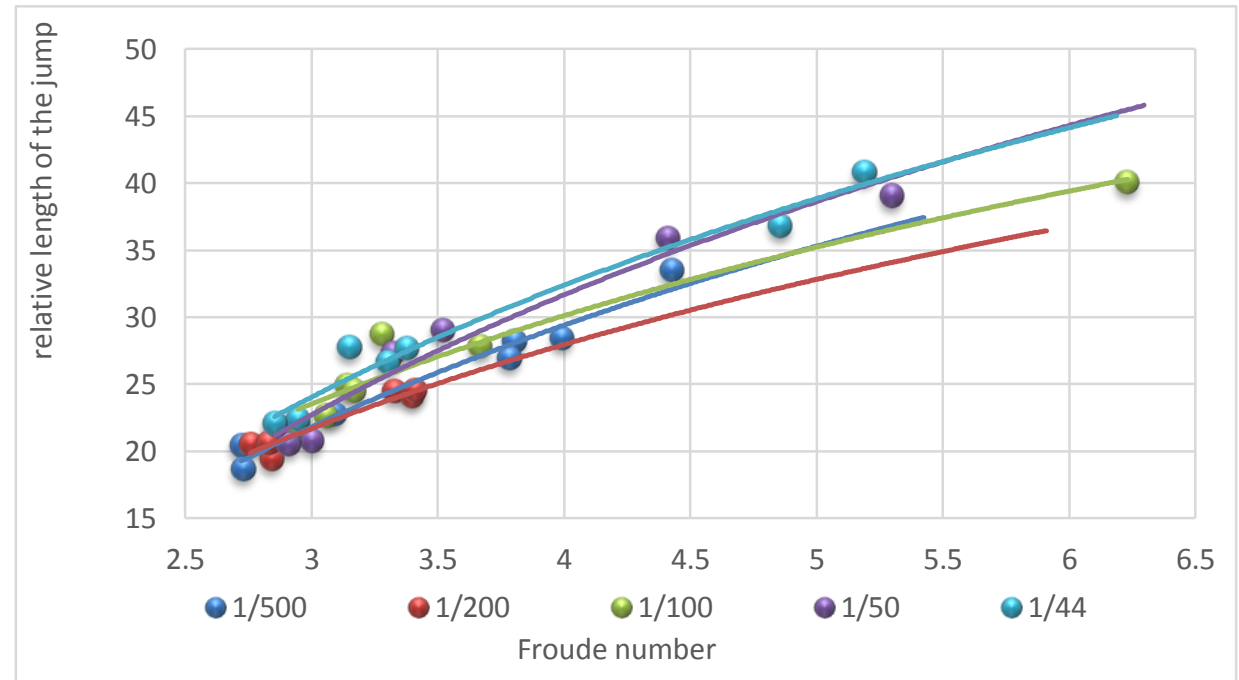

Figure (16): The relationship between Fr1 and $\mathrm{Lj} / \mathrm{y} 1$ for different bed slopes, (b) for $\mathrm{w}=18 \mathrm{~cm}$.



Figure (17): The relationship between Fr1 and y2/y1 for $\mathrm{w}=18.0 \mathrm{~cm}$, different bed slopes and $\mathrm{Se} 1=3.5 \mathrm{~cm}$, for $\mathrm{hb}=4 \mathrm{~cm}$. 


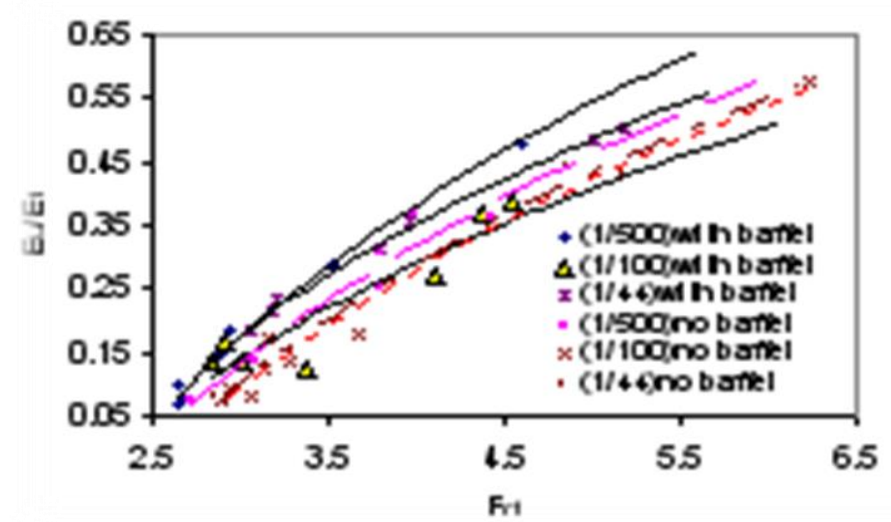

Figure (18): The relationship between Fr1 andEL/E1 for $\mathrm{w}=18.0 \mathrm{~cm}$, different bed slopes and $\mathrm{Se} 1=3.5 \mathrm{~cm}$, for $\mathrm{hb}=4 \mathrm{~cm}$.

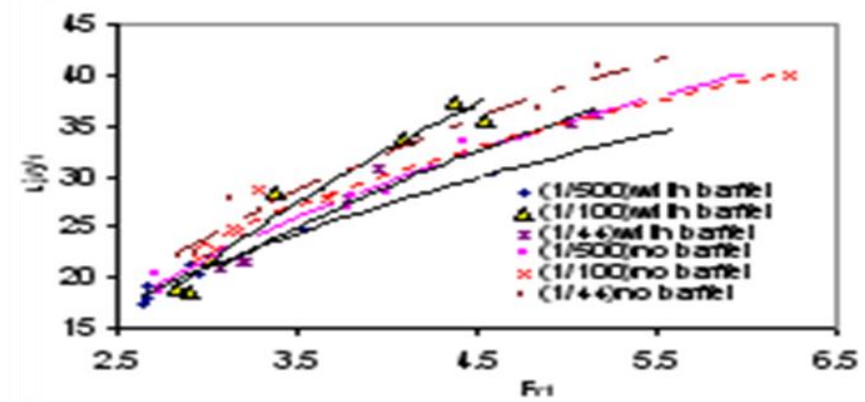

Figure (19): The relationship between Fr 1 andLj/y1 for $\mathrm{w}=518.0 \mathrm{~cm}$, different bed slopes and $\mathrm{Se} 1=3.5 \mathrm{~cm}$, for $\mathrm{hb}=4 \mathrm{~cm}$.

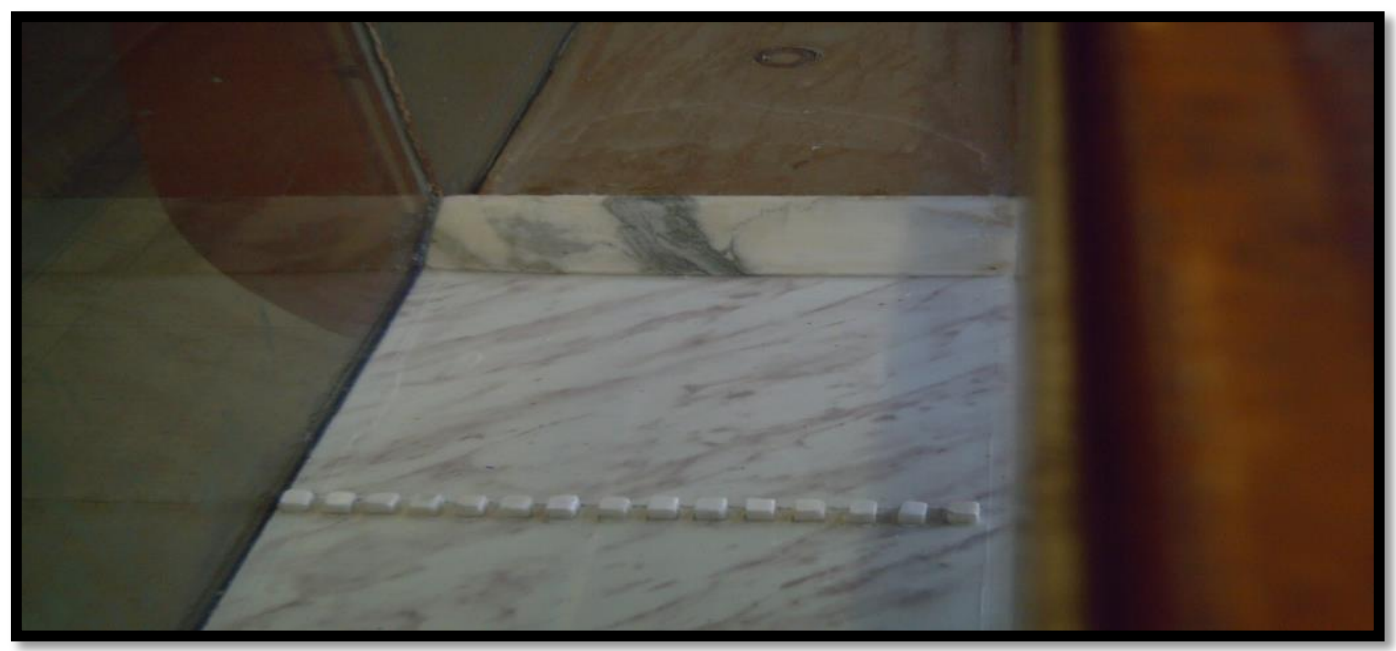

Figure (20): a photo for experimental setup for the end sill and baffle blocks 




Figure (21): a photo for the baffle blocks with different sizes.

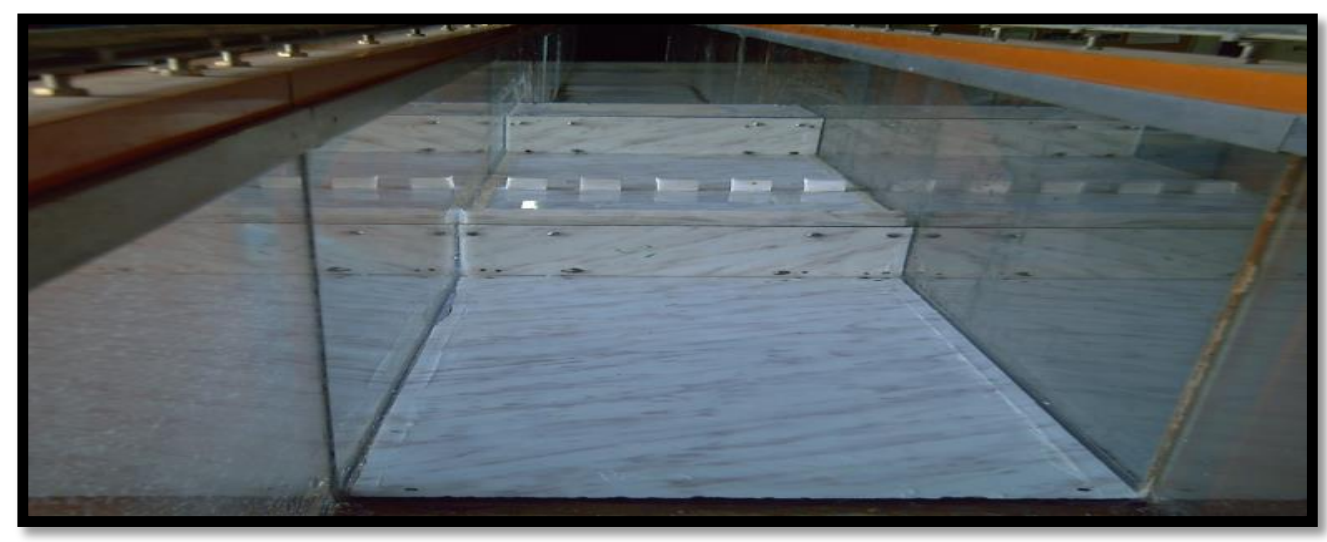

Figure (22): a photo for experimental setup for flat case in the lower basin.



Figure (23): the relationship between Fr1 and (E1-E5)/E1 for $\mathrm{w}=12.0 \mathrm{~cm}, \mathrm{hb}=3 \mathrm{~cm}$ and different bed slopes, (a) for $\mathrm{Se} 1=3.5 \mathrm{~cm}$. 




Figure (24): the relationship between Fr1 and (E1-E5)/for $w=12.0 \mathrm{~cm}, \mathrm{Se} 2=3.3 \mathrm{~cm}, \mathrm{hb}=3 \mathrm{~cm}$ and differeE1 nt bed slopes, (a) for $\mathrm{Se} 1=3.5 \mathrm{~cm}$.



Figure (25): Photo for experimental setup for case of presence of end sill and baffle blocks.



Figure (26): The relationship between Fr1 and (E1-E3)/E1 for $\mathrm{w}=12.0 \mathrm{~cm}, \mathrm{Se} 2=3.3 \mathrm{~cm}$, $\mathrm{hb}=3 \mathrm{~cm}$ and different bed slopes and $\mathrm{hb} 1$, (c) for $\mathrm{Se} 1=6.3 \mathrm{~cm}$. 




Figure (27): The relationship between Fr1 and (E3-E5)/E3 for $\mathrm{w}=12.0 \mathrm{~cm}, \mathrm{Se} 2=3.3 \mathrm{~cm}$, $\mathrm{hb}=3 \mathrm{~cm}$ and different bed slopes and hb1 (c) for $S e 1=6.3 \mathrm{~cm}$.



Figure (28): The relationship between Fr1 and (E1-E5)/E1 for $\mathrm{w}=12.0 \mathrm{~cm}, \mathrm{Se} 2=3.3 \mathrm{~cm}$, $\mathrm{hb}=3 \mathrm{~cm}$ and different bed slopes and $\mathrm{hb} 1,(\mathrm{c})$ for $\mathrm{Se} 1=6.3 \mathrm{~cm}$. 


\title{
دراسة مختبرية لتثتيت الطاقة باستخذام احواض التهائة احادية وثنائية المهابط
}

\author{
قاسم حميد جلعوط 1 نجلة فرج البعجة 2





عملية الحفر في المناطق اسفل المنشآت الهيدروليكية واحدة من اهم العوامل التي تؤئز على استقرارية وتثغيل تلك المنشآت. الطاقة المتولدة الكبيرة في منطقة اسفل المنشاءات يجب ان يتم السيطرة عليها. لذلك يجب تصميم منشأت التتتت لتبديد هذه الطاقة الكبيرة والحد من اعمال الحفر المراققة لها. احواض التهيئة ذات المهابط الاحادية او المتعددة واحدة من تلك المنشاءات المستخدمة. في الدراسة الحالية تم استخدام النماذج المختبرية لأحواض تهرئة مختلفة الابعاد احادية المهبط و ثنائية المهابط المتعاقبة. كما ونت دراسة تأثثر استخدام العتبات النهائية و المصدات بمختلف الاحجام والميول في احواض التهيئة. المتغيرات الهيدروليكية المصاحبة لجريان الماء في تلك الاحواض تم قياسها باستخدام قناة


استخدام العتبة النهائية قد قللت طول القزة الهيدروليكية بنسبة 4\% مع فئه زيادة بسيطة في فقدان الطاقة. زيادة ارتفاع

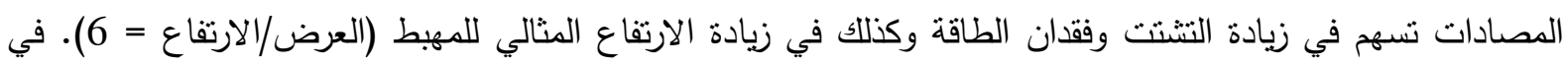
حالة المهابط الثنائية وجد ان فقدان الطاقة الاكبر يكون في المهبط الثاني. وجود العتبة النهائية في المهبط الثاني يزيد من قابلية حوث التهدئة بتشتيت الطاقة وبنسبة 5\% نقريبا. وكذلك وجد ان زيادة ارتفاع المصدات يزيد من قابلية التشتت تحت ظروف التجارب المستخدمة تحت المحددات التالية: (optimum relative baffle block height $h_{b} / y_{l}=0.77$ to 1.7 and bed slope is $1 / 50$ ) 